\title{
BIO-TREATMENT OF SOIL FROM INTERNATIONAL AIRPORT IN OSTRAVA
}

\author{
PETER FEČKO, RADMILA KUČEROVÁ, EVA PERTILE, \\ LUCIE NEZVALOVÁ, NIKOLAS MUCHA, \\ IVA JANÁKOVÁ, VLADIMÍR ČABLÍK \\ VSB - Technical University of Ostrava, Faculty of Mining and Geology, \\ 17. listopadu 15, 70833 Ostrava - Poruba, Czech Republic (peter.fecko@vsb.cz)
}

\begin{abstract}
The paper deals with an examination of possible application of biodegradation in the decontamination of soil samples from international airport in Ostrava. The laboratory biodegradation tests were carried out with a pure bacterial culture of Pseudomonas putida, a pure laboratory culture of Rhodococcus sp, their mixture and a mixture prepared combining their media free of bacteria. The results of the paper imply that for biodegradation of airport pollutants is most suitable to apply a mixed bacterial culture of Pseudomonas putida and Rhodococcus sp. The results show that the biodegradation method is applicable for the pollution.
\end{abstract}

Keywords: biodegradation, Pseudomonas putida, Rhodococcus sp., mixed culture

\section{Introduction}

Biodegradation (biological decontamination) is grounded in the capacity of certain bacterial strains to use hydrocarbons as a source of carbon and energy for their growth and in this way, decomposition of contaminants occur all the way to harmless products - carbon dioxide and water. In short, biodegradation is a special case of degradation during which decomposition of polymers takes place due to the action of biological factors. It makes part of natural processes taking place in water and soil. For example, there is spontaneous degradation of biologically degradable oil substances at contamination of soil by oil substances. However, the process is slow and meanwhile contamination may spread into the surroundings. In the locality some resistant substances remain. In order to speed up the rate of degradation, it was necessary to make the process more intense and to remove resistant substances bacterial mixtures may be utilized.

The ability of microorganisms to degrade hydrocarbons has been known since 1895, when Miyoshi described growth of yeast on paraffin and shortly after the capacity of bacteria to make use of methane as a source of carbon was discovered. Gradually, it was demonstrated that they are able to decompose practically all components of crude oil and many other hydrocarbons. At present, over 200 types of microorganisms have been described that are able to degrade hydrocarbons. Some are able to make use of one hydrocarbon only (e.g. methane), but no microbial strain is known to degrade a whole range of hydrocarbons present in crude oil, for example. Therefore, these are rather microbial associations that participate in degradation (NOVOTNÝ, 2005).

The objective of the paper was to examine the application of bacterial leaching to the decontamination of soil samples from the Leos Janacek Airport in Ostrava - these samples were taken from two sampling points. 


\section{Materials and methods}

\subsection{Leos Janacek Airport in Ostrava}

The first mention of air traffic at the territory of the present airport is from 1939 when German Luftwaffe built a field aerodrome to attack Poland. The modern history began in 1956 when the current airport began to be constructed. Before 1989, the airport was used mainly for the needs of the air force. Civil aviation was ensured by CSA, namely for domestic flights, rarely for international ones. A significant turning point was the year of 1993 when the military traffic was terminated at the airport. On 13 December 2006 the airport was ceremonially christened after the composer of Leos Janacek and a new departure hall was put into operation. With regard to its excellent technical parameters, a pronounced development of this traffic junction is expected in the future (see references).

Several oil leaks have occurred at the airport and Figure 1 and Figure 2 show an oil interceptor Lapol D and Lapol 2, which intercepts leaks of hazardous substances. Table 1 summarizes leaks of hazardous substances since 2005. At the same time, it gives substances that penetrated into the environment and the materials by used for their elimination.

Table 1. Leaks of oil substances at the airport.

\begin{tabular}{|c|c|c|c|c|c|}
\hline Date & Leak locality & Substance & $\begin{array}{c}\text { Qty of } \\
\text { leaked } \\
\text { subst. [1 ] }\end{array}$ & $\begin{array}{c}\text { Material } \\
\text { used } \\
\text { for disposal } \\
\end{array}$ & $\begin{array}{c}\text { Leak into } \\
\text { sewer } \\
\text { system } \\
\end{array}$ \\
\hline 23.6 .2005 & $\begin{array}{c}\text { Central passenger } \\
\text { terminal }\end{array}$ & JET A - 1 & 200 & $\begin{array}{l}\text { Vapex, } \\
\text { Cansorb }\end{array}$ & $\mathrm{NO}$ \\
\hline 21.6 .2006 & $\begin{array}{c}\text { Central passenger } \\
\text { terminal }\end{array}$ & JET A - 1 & Not determ. & Cansorb & $\mathrm{NO}$ \\
\hline 28.7 .2006 & $\begin{array}{c}\text { Central passenger } \\
\text { terminal }\end{array}$ & Hydraulic oil & Not determ. & Cansorb & $\mathrm{NO}$ \\
\hline 12.9.2006 & $\begin{array}{c}\text { Central passenger } \\
\text { terminal }\end{array}$ & JET A - 1 & Not determ. & Cansorb & $\mathrm{NO}$ \\
\hline 18.9.2006 & Taxiway & JET A - 1 & 50 & $\begin{array}{l}\text { Vapex, } \\
\text { Cansorb, wa } \\
\text { ter, surface- } \\
\text { active agent }\end{array}$ & $\mathrm{NO}$ \\
\hline 27.9 .2006 & Northern stand & JET A - 1 & 30 & Cansorb & $\mathrm{NO}$ \\
\hline 29.3.2007 & $\begin{array}{c}\text { Central passenger } \\
\text { terminal }\end{array}$ & JET A - 1 & 30 & Cansorb & $\mathrm{NO}$ \\
\hline 28.3.2008 & $\begin{array}{l}\text { Bunkers of } \\
\text { airport } \\
\text { propellants }\end{array}$ & $\begin{array}{c}\text { Oil products - } \\
\text { closely } \\
\text { unspecified }\end{array}$ & Not determ. & $\begin{array}{c}\text { Vapex, } \\
\text { sorption } \\
\text { layer, } \\
\text { absorption } \\
\text { heaps, } \\
\text { sewer seal }\end{array}$ & YES \\
\hline
\end{tabular}


It is apparent from the table that accidents with environmental impact prevail, accompanied by leaks of aviation turbine fuel JET A-1.

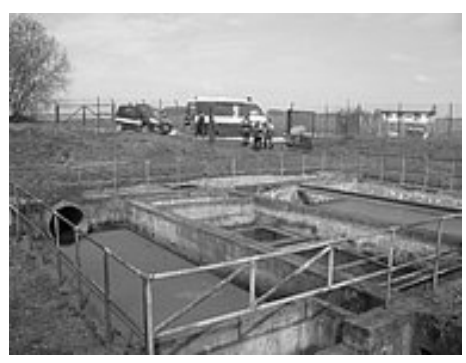

Fig. 1. Lapol D - leaks of oil products.

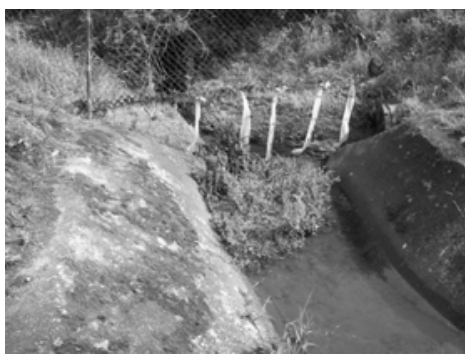

Fig. 2. Lapol 2.

\subsection{Characteristics of drawn samples}

The soil samples were taken directly from the airfield of the Leos Janacek Airport in Ostrava - Mosnov - see Figure 3.

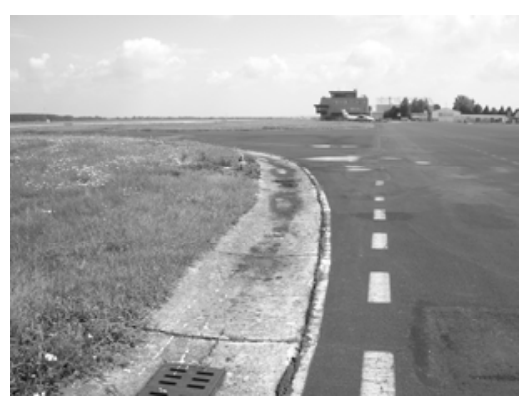

Fig. 3. View of the sampling point.

The mineralogical analyses were implemented in the laboratories of the Institute of Geological Engineering at Mining College - Technical University of Ostrava by means of an X-ray diffraction. The results of the mineralogical analyses of sample 1 (Figure 4) imply that the samples contain about $18 \%$ of amorphous phase, majority of quartz - about $57 \%$ and followed by calcite, chlorite, muscovite, orthoclase and albite.

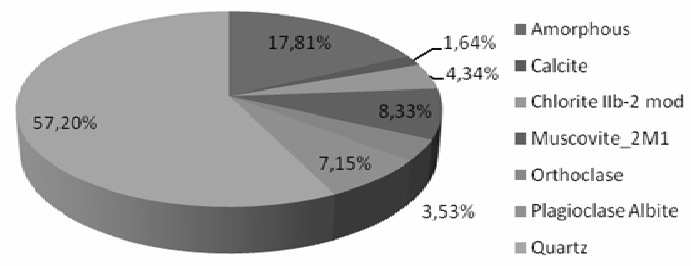

Fig. 4. Mineralogical analysis of the sample No.1. 
The results of the mineralogical analyses of sample 2 (Figure 5) imply that the samples contain about $30 \%$ of amorphous phase, majority of quartz - about $42 \%$. .

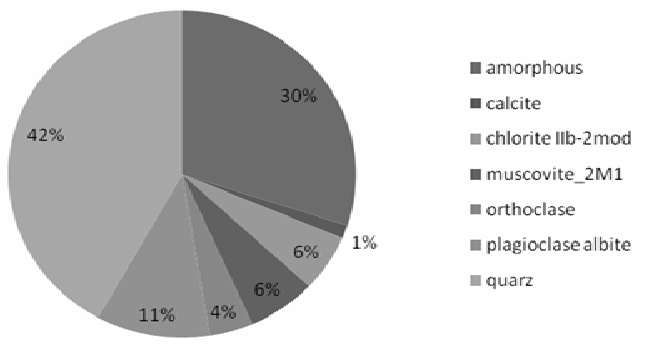

Fig. 5. Mineralogical analysis of the sample No.2.

\subsection{Characteristics of bacterial cultures and the method of laboratory tests}

For biodegradation of the samples, pure bacterial cultures of Pseudomonas putida and Rhodococcus $s p$ were used. The bacterial cultures are shown in Figures 6 A, B (FEČKO et al., 2004).
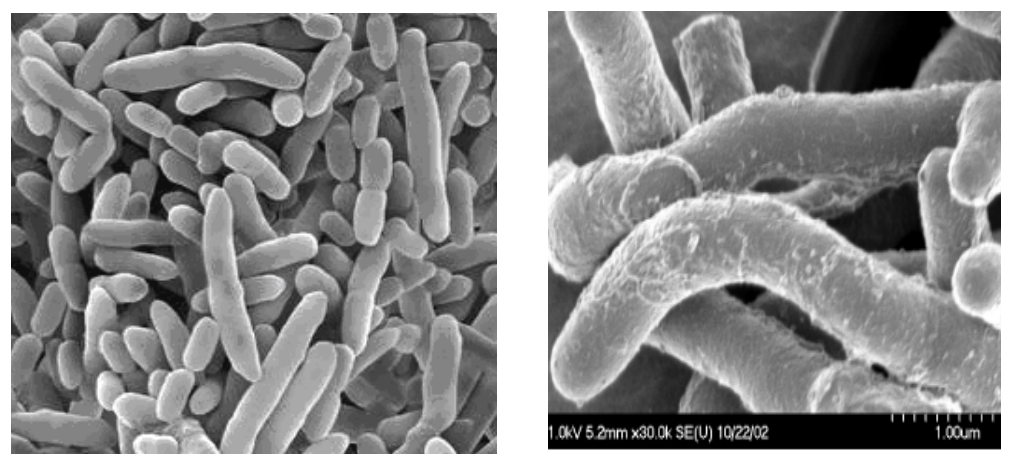

Fig. 6. Pseudomonas putida (A) and Rhodococcus sp. RHA1 (B) (FEČKO et al., 2004).

The culture media were the liquid medium of M1 for Pseudomonas putida and medium of M96 for Rhodococcus sp.

The laboratory experiments were carried out with pure bacterial cultures of Psedomonas putida and Rhodococcus sp., mixed culture and bacterial medium made of 50 $\%$ MI medium and $50 \%$ of M96 medium. The experiments were carried out in the laboratories of the Institute of Environmental Engineering at VSB-TU Ostrava, where 28day bacterial degradation took place. Each sample was placed into a 21 glass beaker. Aeration was secured by means of aquarium pumps placed into the beakers. The necks of the beakers were sealed with a foil and then the beakers were moved into the chemical hood. In the course of 4-week degradation the volume in the beakers was regularly filled with distilled water as gradual evaporation occurred. Having finished the experiment, the samples were filtered, dried and sent to further chemical analyses into the Brown Coal Research Institute in Most. 


\section{Results and discussion}

The results of laboratory biodegradation tests after one-month biodegradation with applied pure bacterial cultures and mixed culture are stated in Tables 2, 3. The tables imply that in the course of biodegradation tests, gradual degradation of harmful substances content from the sample occurred. For biodegradation the following pure bacterial cultures were used: Pseudomonas putida - PP, Rhodococcus $s p$. - R, mixed culture Rhodococcus $s p$. and Pseudomonas putida $-R+P P$, and a check sample from media mixtures $-K$.

Table 2. Course of degradation the selected contaminants by means of Rhodococcus - R, Pseudomonas putida $\boldsymbol{P P}$ and mixed culture $\boldsymbol{P P}+\boldsymbol{R}$, check test $-\mathbf{K}$

\begin{tabular}{|c|c|c|c|c|c|c|c|c|c|}
\hline \multicolumn{10}{|c|}{ Evaluation of the biodegradation test of sample 1} \\
\hline \multirow{2}{*}{ Parameter } & Input & $\mathbf{R}$ & $\begin{array}{c}\text { Removal } \\
\text { degree }\end{array}$ & PP & $\begin{array}{c}\begin{array}{c}\text { Removal } \\
\text { degree }\end{array} \\
\end{array}$ & $\mathbf{P P}+\mathbf{R}$ & $\begin{array}{c}\begin{array}{c}\text { Removal } \\
\text { degree }\end{array} \\
\end{array}$ & $\begin{array}{l}\text { Check } \\
\text { test - K } \\
\end{array}$ & $\begin{array}{c}\begin{array}{c}\text { Removal } \\
\text { degree }\end{array} \\
\end{array}$ \\
\hline & $\mathrm{mg} / \mathrm{kg}$ & $\mathrm{mg} / \mathrm{kg}$ & $\%$ & $\mathrm{mg} / \mathrm{kg}$ & $\%$ & $\mathrm{mg} / \mathrm{kg}$ & $\%$ & $\mathrm{mg} / \mathrm{kg}$ & $\%$ \\
\hline NEL $\left.{ }^{*}\right)$ & 196 & 127 & 35.2 & 120 & 38.78 & 72 & 63.27 & 89 & 54.59 \\
\hline anthracene & 11.4 & 1.3 & 88.6 & 1.03 & 90.96 & 2.22 & 80.53 & 4.28 & 62.46 \\
\hline $\begin{array}{l}\text { benzo(a) } \\
\text { anthracene }\end{array}$ & 65.8 & 8.2 & 87.54 & 5.83 & 91.14 & 12.88 & 80.43 & 29.09 & 55.79 \\
\hline $\begin{array}{l}\text { benzo(b) } \\
\text { fluoranthene }\end{array}$ & 67.2 & 11.51 & 82.87 & 7.74 & 88.48 & 14.61 & 78.26 & 40.22 & 40.15 \\
\hline $\begin{array}{l}\text { benzo(k) } \\
\text { fluoranthene }\end{array}$ & 61.2 & 54.16 & 11.5 & 5.97 & 90.25 & 11.81 & 80.7 & 27.36 & 55.29 \\
\hline $\begin{array}{l}\text { benzo(a) } \\
\text { pyrene }\end{array}$ & 105 & 102.29 & 2.58 & 3.71 & 96.47 & 5.78 & 94.5 & 17.66 & 83.18 \\
\hline $\begin{array}{l}\text { benzo(ghi) } \\
\text { perylene }\end{array}$ & 56.5 & 49.76 & 11.93 & 3.09 & 94.53 & 6.13 & 89.15 & 14.31 & 74.67 \\
\hline Fenantrene & 208.8 & 32.03 & 84.66 & 22.69 & 89.13 & 46.36 & 77.8 & 114.38 & 45.22 \\
\hline fluoranthene & 264 & 24.05 & 90.89 & 18.88 & 92.85 & 36 & 86.36 & 96.96 & 63.27 \\
\hline chrysene & 86.9 & 0.32 & 99.63 & 0.72 & 99.17 & 16.41 & 81.12 & 42.57 & 51.01 \\
\hline $\begin{array}{c}\text { Indeno } \\
(1,2,3-d) \text { pyrene }\end{array}$ & 18.7 & 0.1 & 99.47 & 11.98 & 35.94 & 4.44 & 76.26 & 18.67 & 0.16 \\
\hline naftalene & 12.3 & 1.35 & 89.02 & 0.95 & 92.28 & 2.14 & 82.6 & 3.71 & 69.84 \\
\hline pyrene & 230.9 & 4.08 & 98.23 & 12.45 & 94.61 & 25.16 & 89.1 & 64.17 & 72.21 \\
\hline$\Sigma$ PAH & 1188.7 & 289.15 & 75.68 & 95.04 & 92 & 183.94 & 84.53 & 473.38 & 60.18 \\
\hline PCB 28 & 0.01 & 0.01 & 0 & 0.01 & 0 & 0.01 & 0 & 0.01 & 0 \\
\hline PCB 52 & 0.01 & 0.01 & 0 & 0.01 & 0 & 0.01 & 0 & 0.01 & 0 \\
\hline PCB 101 & 0.01 & 0.01 & 0 & 0.01 & 0 & 0.01 & 0 & 0.01 & 0 \\
\hline PCB 118 & 0.02 & 0.01 & 50 & 0.01 & 50 & 0.01 & 50 & 0.02 & 0 \\
\hline PCB 138 & 0.02 & 0.02 & 25 & 0.02 & 25 & 0.01 & 45 & 0.02 & 0 \\
\hline PCB 153 & 0.06 & 0.02 & 57.89 & 0.04 & 36.84 & 0.02 & 59.65 & 0.04 & 24.56 \\
\hline PCB 180 & 0.02 & 0.01 & 50 & 0.02 & 15 & 0.01 & 50 & 0.01 & 50 \\
\hline$\Sigma$ PCB & 0.15 & 0.09 & 39.46 & 0.11 & 26.53 & 0,08 & 42.86 & 0.12 & 16.33 \\
\hline
\end{tabular}

*) NEL - hydrocarbons $\mathrm{C}_{10}-\mathrm{C}_{40}$ 
It is apparent from the results of four-week biodegradation test that the most suitable application for the sample 1 is that of the pure bacterial cultures of Pseudomonas putida, where the degradation of contaminants of PAH was $92 \%$.

In terms of degradation of PCB the best was the application of mixed culture, i.e. $42.9 \%$. In this case, the efficiency of the mixed bacterial culture was very positive as is visible from the following removed quantities: $63.3 \%$ of NEL, $84.50 \%$ of PAH and $42.9 \%$ of $\mathrm{PCB}$.

Table 3. Course of degradation the selected contaminants by means of Rhodococcus - R, Pseudomonas putida $\boldsymbol{P P}$ and mixed culture $\boldsymbol{P P}+\boldsymbol{R}$, check test $-\mathbf{K}$.

\begin{tabular}{|c|c|c|c|c|c|c|c|c|c|}
\hline \multicolumn{10}{|c|}{ Evaluation of the biodegradation test of sample 2} \\
\hline Parameter & Input & $\mathbf{R}$ & $\begin{array}{c}\text { Removal } \\
\text { degree }\end{array}$ & PP & $\begin{array}{c}\text { Removal } \\
\text { degree }\end{array}$ & $\mathbf{P P}+\mathbf{R}$ & $\begin{array}{c}\text { Removal } \\
\text { degree }\end{array}$ & $\begin{array}{c}\text { Check } \\
\text { test - } \\
\text { K } \\
\end{array}$ & $\begin{array}{c}\text { Removal } \\
\text { degree }\end{array}$ \\
\hline & $\mathrm{mg} / \mathrm{kg}$ & $\mathrm{mg} / \mathrm{kg}$ & $\%$ & $\mathrm{mg} / \mathrm{kg}$ & $\%$ & $\mathrm{mg} / \mathrm{kg}$ & $\%$ & $\mathrm{mg} / \mathrm{kg}$ & $\%$ \\
\hline NEL & 150 & 100 & 33.3 & 60 & 60 & 35 & 76.6 & 120 & 20 \\
\hline antracene & 0.7 & 0.49 & 30 & 0.07 & 90 & 0.1 & 85.71 & 0.12 & 82.86 \\
\hline $\begin{array}{l}\text { benzo(a) } \\
\text { antracene }\end{array}$ & 2.36 & 1.89 & 19.92 & 0.33 & 86.02 & 0.44 & 81.36 & 0.48 & 79.66 \\
\hline $\begin{array}{c}\text { benzo(b) } \\
\text { fluoranthene }\end{array}$ & 5.2 & 4.95 & 4.81 & 0.6 & 88.46 & 0.69 & 86.73 & 0.71 & 86.35 \\
\hline $\begin{array}{c}\text { benzo(k) } \\
\text { fluoranthene }\end{array}$ & 3.1 & 2.99 & 3.55 & 0.43 & 86.13 & 0.54 & 82.58 & 0.59 & 80.97 \\
\hline $\begin{array}{l}\text { benzo(a) } \\
\text { pyrene }\end{array}$ & 5.31 & 4,67 & 12.05 & 0.53 & 90.02 & 0.59 & 88.89 & 0.74 & 86.06 \\
\hline $\begin{array}{l}\text { benzo(ghi) } \\
\text { perylene }\end{array}$ & 3.5 & 1.16 & 66.86 & 0.21 & 94 & 0.27 & 92.29 & 0.28 & 92 \\
\hline fenantrene & 2.65 & 2.45 & 7.55 & 0.86 & 67.55 & 0.14 & 94.72 & 1.45 & 45.28 \\
\hline fluoranthene & 5.7 & 0.27 & 95.26 & 0.19 & 96.67 & 0.41 & 92.81 & 0.58 & 89.82 \\
\hline chrysene & 2.7 & 0.13 & 95,19 & 0.25 & 90.74 & 0.02 & 99.26 & 0.02 & 99.26 \\
\hline $\begin{array}{c}\text { indeno }(1,2,3-\mathrm{cd}) \\
\text { pyrene }\end{array}$ & 6.99 & 6.66 & 4.72 & 2.39 & 65.81 & 0.11 & 98.43 & 0.56 & 91.99 \\
\hline naftalene & 0.09 & 0.07 & 22.22 & 0.07 & 22.22 & 0.07 & 22.22 & 0.07 & 22.22 \\
\hline pyrene & 4.75 & 2.69 & 43.37 & 0.6 & 87.37 & 0.17 & 96.42 & 1.3 & 72.63 \\
\hline$\Sigma$ PAH & 43.05 & 28.42 & 33.98 & 6.53 & 84.83 & 3.55 & 91.75 & 6.9 & 83.97 \\
\hline PCB 28 & $<0.01$ & $<0.01$ & - & $<0.01$ & - & $<0.01$ & - & $<0.01$ & - \\
\hline PCB 52 & $<0.01$ & $<0.01$ & - & $<0.01$ & - & $<0.01$ & - & $<0.01$ & - \\
\hline PCB 101 & $<0.01$ & $<0.01$ & - & $<0.01$ & - & $<0.01$ & - & $<0.01$ & - \\
\hline PCB 118 & $<0.01$ & $<0.01$ & - & $<0.01$ & - & $<0.01$ & - & $<0.01$ & - \\
\hline PCB 138 & $<0.01$ & $<0.01$ & - & $<0.01$ & - & $<0.01$ & - & $<0.01$ & - \\
\hline PCB 153 & $<0.01$ & $<0.01$ & - & $<0.01$ & - & $<0.01$ & - & $<0.01$ & - \\
\hline PCB 180 & $<0.01$ & $<0.01$ & - & $<0.01$ & - & $<0.01$ & - & $<0.01$ & - \\
\hline$\Sigma 7$ PCB & $<0.07$ & $<0.07$ & - & $<0.07$ & - & $<0.07$ & - & $<0.07$ & - \\
\hline
\end{tabular}

*) NEL - hydrocarbons $\mathrm{C}_{10}-\mathrm{C}_{40}$ 
It is apparent from the results of four-week biodegradation test that the most suitable application for the sample 2 is that of mixed bacterial cultures of Pseudomonas putida and Rhodococcus, where the degradation of contaminants of PAH was $91.75 \%$. The amount of PCB was lower as detection limit.

In this case, the efficiency of the mixed bacterial culture was very positive as is visible from the following removed quantities: $76.6 \%$ of NEL, $84.83 \%$ of PAH and 0 $\%$ of PCB.

\section{Conclusions}

The objective of the paper was to examine the application of biodegradation in the decontamination of soil sample from the Leos Janacek Airport in Ostrava.

For the laboratory biodegradation tests soil samples from the airport of the Leos Janacek in Ostrava - Mosnov was used. The laboratory biodegradation tests were implemented with pure bacterial culture of Pseudomonas putida, pure bacterial culture of Rhodococcus $s p$, their mixture and mixture made combining their media free of bacteria.

The efficiency of the biodegradation of sample 1 after one-month leaching with pure bacterial culture of Pseudomonas putida (PP) was $38.8 \%$ for NEL, $92 \%$ for PAH, $26.5 \%$ for PCB, by means of pure bacterial culture of Rhodococcus sp. (R) was $35.2 \%$ for NEL, $75.7 \%$ for PAH, $39.5 \%$ for PCB, by means of mixed bacterial culture it was $63.3 \%$ for NEL, $84.5 \%$ for PAH, and $42.9 \%$ for PCB.

The efficiency of the biodegradation of sample 2 after one-month leaching with pure bacterial culture of Pseudomonas putida (PP) was $60 \%$ for NEL, $84.5 \%$ for PAH, $0 \%$ for PCB, by means of pure bacterial culture of Rhodococcus $s p$. (R) was $33.3 \%$ for NEL, $28.5 \%$ for $\mathrm{PAH},<0.07 \%$ for $\mathrm{PCB}$, by means of mixed bacterial culture it was $76.6 \%$ for NEL, $91.8 \%$ for PAH and $0 \%$ for PCB.

The paper results imply that the laboratory sample 1 biodegradation efficiency with the selected contaminants ranged from $35.2-63.3 \%$ for NEL, $60.2-92 \%$ for PAH and $16.3-42.9 \%$ for PCB.

The paper results imply that the biodegradation efficiency of laboratory sample 2 with the selected contaminants ranged from $33.3-76.6 \%$ for NEL, $33.98-91.75 \%$ for PAH. The amount of PCB was lower as detection limit.

The best efficiency was obtained in the laboratory biodegradation of PAH. Intermediate efficiency was reached with biodegradation of NEL and PCB. The highest amount of NEL and PCB were removed by mixed bacterial culture ( $\mathrm{PP}+\mathrm{R})$. For soil biodegradation, it is thus the most suitable to apply the mixed bacterial culture of Pseudomonas putida and Rhodococcus sp.

The results demonstrate that for the given type of contamination the method of biodegradation is suitable.

Acknowledgement: The work was carried out within the VaV SP/2f2/98/07 Project solution "Research in the Utilization of Waste as Substitutes for Primary Raw Material Sources" and supported by the Ministry of Environment (MoE) of the CR. 


\section{References}

NOVOTNÝ, C.: Biodegradace a biotechnologie, Ostravska univerzita, Ostrava, 2005. $96 \mathrm{pp}$.

Basic information on the airport [online]. 2009 [cit. 2009-03-02]. Available from WWW: <http://www.airport-ostrava.cz/cz/page-zakladni informace $>$.

History of the airport [online]. 2008 [cit. 2009-03-02]. Available from WWW: $<$ www.airport-ostrava.cz/cz/page-historie-vznik-vyvoj>.

Technical data on the airport [online]. 2008 [cit. 2009-03-02]. Available from WWW: $<$ http://www.airport-ostrava.cz/cz/page-technicke-udaje $>$.

Mosnov municipality [online]. 2009 [cit. 2009-03-02]. Available from WWW: $<\mathrm{http}: / /$ www.mosnov.cz/index.php?lang=1\&str=002>.

FECKO, P. et al.: Environmentalní biotechnologie, Ostrava, VSB- TU Ostrava, 2004. $180 \mathrm{pp}$. 